\title{
A Firm-Level Analysis of Migration to E-Commerce in Serbia
}

\author{
Zlatko J. Kovačić \\ Open Polytechnic, \\ Wellington, New Zealand
}

\author{
Dragan Vukmirović \\ Statistical Office of the \\ Republic of Serbia, \\ Belgrade, Serbia
}

\section{Zlatko.Kovacic@openpolytechnic.ac.nz Dragan.Vukmirovic@stat.gov.rs}

\begin{abstract}
Only
This paper explores factors such as technological infrastructure, the use of information technology and other factors (firm size, location and industry type) that may influence the migration to ecommerce at the firm-level. We examine to what extent these factors contribute to the level of migration to e-commerce among firms in Serbia. The level of migration is measured by the percentage of total turnover from orders placed on the internet.
\end{abstract}

We used the cross-sectional data from the 2009 and 2010 "ICT usage in Republic of Serbia" surveys, covering over 2000 firms, to perform a quantitative analysis of the migration to ecommerce. Based on results from the hierarchical regression models it was found that only a small fraction of variation (14.9\%) in the level of migration to e-commerce is explained by the factors included in our conceptual model. While each of the blocks: structural characteristics, eskills and the technology adoption is statistically significant in explaining the variation in the level of migration to e-commerce, this is not the case with the technology use block.

The empirical results show the following: (i) small size firms achieved a higher level of migration than the middle sized firms; (ii) surprisingly, firms in the service industry and manufacturing are more intensively involved in e-commerce than retail industry firms; (iii) Firms with skilled employees regularly accessing the internet are more likely to have a higher percentage of sales made online; (iv) technology adoption (having a website, digital signature and security protocols in particular), as a prerequisite for migration to e-commerce, has a significant impact, but does not guarantee the success online business; and (v) surprisingly, the use of technology for running a business both within the firm and externally with clients or business partners does not have a significant effect on the firm's migration to e-commerce.

A representative Serbian firm with the higher level of migration to e-commerce could be described as a small-sized firm with the website and with the wireless connection to the internet.

Material published as part of this publication, either on-line or in print, is copyrighted by the Informing Science Institute. Permission to make digital or paper copy of part or all of these works for personal or classroom use is granted without fee provided that the copies are not made or distributed for profit or commercial advantage AND that copies 1) bear this notice in full and 2) give the full citation on the first page. It is permissible to abstract these works so long as credit is given. To copy in all other cases or to republish or to post on a server or to redistribute to lists requires specific permission and payment of a fee. Contact Publisher@InformingScience.org to request redistribution permission.
This firm will typically operate in the services industry, will be located in Central Serbia, and in which employees will frequently using the internet. The firm will typically have a digital signature and well defined security protocols.

Serbia has a range of challenges to face. The hierarchical regression results show that standard factors used in similar migration to e-commerce studies add little 
to an explanation of why such variation in the level of migration to e-commerce occurred. We believe that national government policy plays a key role in creating a legal framework (e.g. deregulation of telecommunication services) and creative economic and social environment that will encourage further investment in ICT infrastructure and start-up internet businesses, as well as wider public education about the benefits of technology and its use in everyday life and for running businesses. It would be difficult if not impossible to increase a level of e-commerce usage without an overall, consistent governmental policy (e.g. business and tax laws) that would encourage and support such an increase.

Keywords: Technology adoption, migration to e-commerce, use of information technology, firm's structural characteristics, online sales, Serbia, hierarchical regression.

\section{Biographies}

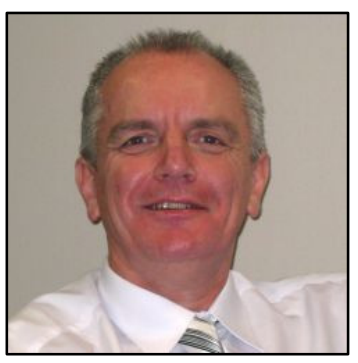

Dr Zlatko J Kovačić is an Associate Professor in the School of Information and Social Sciences at Open Polytechnic. Zlatko has a varied academic background and research interests, ranging from core interests relating to IT learning and teaching, to eCommerce, time series analysis, and multivariate analysis. His current research is focused on cognitive processes in distance education using computers and communications technologies, on social and cultural aspects of information technology and time series analysis of emerging financial markets.

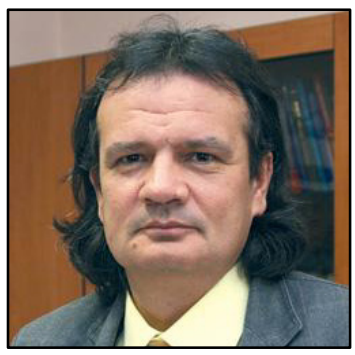

Dr Dragan Vukmirović is a Full Professor in the Faculty of Organizational Sciences at the Belgrade University and Director of the Statistical Office of the Republic of Serbia. Dragan published papers and participated in research projects in the areas of statistics, e-business and marketing. He was founder and coordinator of the master studies in ebusiness and the postgraduate studies on the internet technology and ebusiness at the Faculty of Organizational Sciences. 